\title{
An Investigation of Factors Influencing Audit Quality According to Islamic Audit: A Study for the Jakarta Islamic Index
}

\author{
Helmi Yazid ${ }^{1}$ and Tulus Suryanto ${ }^{2}$
}

\begin{abstract}
:
The purpose of this study is to examine the influence of past audits, auditors' training and auditors' experience on audit quality in companies. The method used was quantitative method.

The research was done on 49 companies listed in the Jakarta Islamic index.The research examines the influence of the education of auditors, audit period, and the auditors' experience on the quality of audits. It can be seen from the $F$ test that produces the value of $F$ count $>$ F table or 5048.932> 1.667.

The high education of auditors, auditor assignment period, and the auditors' experience will further improve the quality of the audits of auditors auditing the companies listed in the Jakarta Islamic Index (JII).
\end{abstract}

Key Words: Audit assignment, auditors' education, experience, quality of audit

\footnotetext{
${ }^{1}$ Faculty of Economics and Business, Sultan Ageng Tirtayasa University, Indonesia. helmiyazid@untirtaac.id

${ }^{2}$ Faculty of Islamic Economic and Business, State Islamic Institute of Raden Intan Lampung, Indonesia.tulus@iainradenintan.ac.id
} 


\section{Introduction}

Audit profession has become the public spotlight. Financial data manipulation cases undertaken by large companies such as Enron, Worldcom, Xerox and others that eventually went bankrupt have caused the public accounting profession to be heavily criticized ${ }^{3}$. In Indonesia, there is a case involving Telkom in relation to the illegitimacy of KAP Eddy Pianto by a shareholder who has a reason why they did not acknowledge the existence of KAP Eddy Pianto.

The scandals recently raised were American International Group (AIG) in 2005 and Satyam Computer Services in 2009. The decline in the credibility of Certified Public Accountants also struck PT Kereta Api (Persero) and PT Myoh TechnologyTbk. in 2005. The company owners were wondering about the independence of the auditors when the management of fraud occurred and questioned whether the auditors increased the value of information available to outsiders. In the accounting profession, there is a fairly complicated problem where on one side of accountants must demonstrate their independence by submitting the audit results to the public in an objective way. On the other hand, they are employed and paid by a company that certainly has its own interests ${ }^{4}$.

Competence and independence are two characteristics to be possessed by auditors. The lack of independence and competence of auditors might be due to the use of the capitalist system. Conventional audit system is value-free and does not consider moral values and ethics set by Islam, despite the fact that the standard setters believe that environmental ethics is an important factor in improving audit quality.

The Model of Western secular ethics (reflected in conventional accounting or auditing) generally proposes a system of ethics apart from religion. Capitalistic approach is not suitable for an Islamic economic system that places the values of high moral, justice and for the benefit of the Muslim Community (Maslahah people). According to Hanif, because of the differences in the economic vision of Islam to the Western economy, Islamic economics (including finance, banking or accounting) should be evaluated within the frame work of their own and use their own criteria ${ }^{5}$.

\footnotetext{
${ }^{3}$ Kasim \& Sanusi, "Emergingissues for auditing in Islamic Financial Institutions: Empiri caleviden cefrom Malaysia." IOSR Journal of Business and Management. Universiti Teknologi MARA, Malaysia.Volume8, Issue5 (Mar.-Apr. 2013), h.1.

${ }^{4}$ Ibnu Irawan et al, "Pengaruh Kompetensi, Skeptisme, Hubungan Klien Dengan Auditor, Ukuran KAP Terhadap Kepuasan Klien Dan Kegunaan Untuk Stakeholder Eksternal Dalam Prespektif Klien.” Jurnal \& Prosiding Simposium Nasional Akuntansi Vol. 17. NTB. (2014). h.1.

${ }^{5}$ Nawal Kasim, Zurai dan Mohd Sanusi,Tatik Mutamimah,and Sigit Handoyo, "Assessingthe current practice of Auditingin Islamic Financial Institutionsin Malaysia and Indonesia", International Journal of Trade, Economics and Finance, Vol. 4, No. 6, December 2013, h. 2.
} 
In fact, Islamic financial institutions in Indonesia, Malaysia and other countries still adopt the conventional audit system ${ }^{6}$. Given that the Islamic financial institutions are still at the early stages, they have no guidelines for sharia-based auditing practices. The default setting for the body of Islamic Financial Institutions (LKS) is called the Accounting and Auditing Standards for Islamic Financial Institutions (AAOIFI). Shahul as quoted by Kasim et al. Revealed the need to improve the accounting to adhere Islamic values if they want to survive for a long time ${ }^{7}$. No transparency of Public Accountants is an indication that audit quality is not good.

Quality of audits should be appropriate auditing standards. However, the difficulty of measuring the quality of the audit is due to the fact that many empirical studies use multiple dimensions or proxy as the representative of the quality of the audit. Auditing standards applicable to financial institutions are Shari'ah auditing standards issued by the Accounting and Auditing Organization for Islamic Financial Institution (AAOIFI). Opinions given by an auditor have information contents; therefore, the information should reflect the real situation. Quality information can only be provided by a qualified auditor. De Angelo states that large scale auditors have more incentive to avoid criticism of auditor reputation damage than the small scale ones ${ }^{8}$. This is contrary to Sidhu and Sharma; Barnes and Huan ; and Margaretta and Fanny, who state that the size of the accounting firm does not affect the provision of audit opinions ${ }^{9}$.

\section{Literature Review}

This study examines whetherthe variablesof assignment period, education, and experience affects audit quality, because the three variables can describe the quality of a good audit. Future assignments seen from Bapeppam rules and practices should not exceed the length of the period of assignment rules specified. Furthermore, the variables of education and experience assessed affect audit quality. It is expected that education both formally and informally can be continuously improved through trainings to deepen the understanding of the auditors required to audit experience.

This research is expected to contribute to the literature of the audit and the audit quality measurement. The implications of this study are expected to be useful for the development of the profession of Certified Public Accountants (AP) in improving the quality of audit services. Ultimately, the quality of audit services is expected to improve the transparency and quality of financial reporting so as to

\footnotetext{
${ }^{6}$ Ibid., h. 6

${ }^{7}$ Ibid., h. 2

${ }^{8}$ Indira Januarti, “Analisis Pengaruh Faktor Perusahaan, Kualitas Auditor, Kepemilikan Perusahaan Terhadap Penerimaan Opini Audit Going Concern (Perusahaan Manufaktur yang Terdaftar di Bursa Efek Indonesia). ", Jurnal dan Prosiding SNA - Simposium Nasional Akuntansi. Vol 12. Universitas Diponegoro.(2009), h.5

${ }^{9}$ Ibid. h. 5
} 
promote the efficiency of capital markets and boost the economy both in general at the global level and in particular in the context of Indonesia. Based on the boundary problem which has been stated, the formulation of the problem in this research is : How does a future audit, the auditor's education and experience influence auditors on audit quality?

The period of audit engagements or also known as auditor rotation is required to overcome the familiarity with clientsto maintain independence. Hamilton and Wright; Petty and Cuganesan; Catanach and Walker; Lin and Liu as cited by Hussain et al. Mentioned that auditor rotation could also bring losses such as loss auditors' familiarity and expertise in the industry and business clients, the negative impact of the cost and quality of the audit, and the restrictions caused by the rotation of audit firms with a number of partners with specialist industry knowledge. Several empirical studies, such as Johnson, Khurana and Reynolds; Myers, Myers and Omer; Kaplan and Mauldin, as cited by Hussain et al. Found that where the rotation period of the assignment of the audit firm is not mandatory, short term tenor examination associated with quality financial is reported to be low, while the long term audit engagement does not appear to produce a decrease in the quality of financial reporting or impressions that harm the independent audit firm among non-investors - Professional; it actually facilitates a better auditor extreme limit management's financial reporting decisions.

Financial auditors are ideally educated, qualified, trained and experienced in their profession. With their high educational competence and experience, the audit quality will be better. The higher education and more training undergone by the auditors, the auditors' knowledge will increase. Auditors will increasingly understand their duties and responsibilities. The education of auditors will be better if the auditors' experience is longer. The longer the experience would affect the increasing number of cases that have been undertaken and solved. Experience from previous cases will assist the auditors in auditing.

Based on the arguments about the audit, the auditor's education and experience, and the quality of audit as has been described above, the hypotheses proposed in this study are as follows :

H0: The period of audit, the auditor's education and experience affect audit quality. H1: The period of audit, the auditor's education and the experience of auditor affect audit quality.

\section{Theoretical Basis}

\section{Understanding The Shariah Audit}

Audit is an important factor to ensure corporate accountability. Further, Shariah audit enables practitioners and users to use the knowledge gained in both the 
conventional and Islamic perspectives audits ${ }^{10}$. The general meaning of Shari'ah audit is to see and supervise, control and report transactions, according to the rules and laws of Islam that are useful, accurate, timely and fair reports for decision making. It is not an easy task to conduct an audit of sharia in capitalistic conditions and competitive conventional financial system.

This problem is further compounded by the decline in moral values, social and economic Islam in Muslim countries including Malaysia and Indonesia, under the pressure of progressive colonialism and cultural domination of the western world for several centuries ago. This led to the neglect of the socio-economic values of Islam by some quarters of Financial Institutions Sharia. Syariah auditors face a major challenge from policy makers and top management who are progressive thinkers and practice diverse religions, besides the lack of a comprehensive Shariah framework examination and lack of expertise ${ }^{11}$.

Shariah audit is a systematic process to obtain sufficient and relevant evidence to form an opinion whether that is the subject of personnel, processes, financial as well as non-financial performance consistent with Shariah rules and principles that are widely accepted by the people of Islam and report to user ${ }^{12}$. Ratings independent and objective assurance designed to add value and improve the level of compliance by financial institutions sharia, with the main objective to ensure an effective system of internal control and for Shari'ah compliance.

Audit Syariah according to Haniffa is ${ }^{13}$ : "a systematic process of objectively obtaining and evaluating evidence regarding assertions by Islam and the social economy to ensure a level of conformity, including the criteria defined by Shariah principles, as recommended by the Sharia Supervisory Board (DPS) and communicating the results to all parties". The concept of sharia audit should be extended to activities related to systems, products, employees, the environment and society. There is a need to develop a framework of sharia examination which is useful to ensure effective compliance purposes of Islamic shari'a financial institutions that can make a positive contribution to the society in general ${ }^{14}$.

\footnotetext{
${ }^{10}$ Suharli, M. (2006). Audit Finansial, Audit Manajemen dan Sistem Pengendalian Intern. Jurnal Bisnis dan Ekonomi,(Online), Volume3, No.1. pp 36-37

${ }^{11}$ Nawal Kasim, Zuraidah Mohd Sanusi,Tatik Mutamimah, \& Sigit Handoyo, Assessing the current practice ofAuditingin Islamic Financial Institutions in Malaysia and Indonesia", International Journal of Trade, Economics and Finance, Vol. 4, No. 6, December 2013, h. 6 ${ }^{12}$ Zurina Shafii, Nor Aishah Mohd Aliand Nawal Kasim, "Shariah auditin Islamic bank saninsi ghtto the future shariah auditor labourmarketin Malaysia Audit Syariah di bank syariah", Procedia Social and behavioral science, 2014, www.sciencedirect.com, h. 2

${ }^{13}$ Yacoob \& Donglah,(2012), "Shari'ahAudit in Islamic Financial Institutions:The Postgraduates' Perspective Audit Syariah di Lembaga Keuangan Islam: Thepascasarjana 'Perspektif." International Journal of Economics and Finance. University of Brunei Darussalam, Brunei. Vol.4,No.12. h.3

${ }^{14}$ Suharli, Op.cit., h. 36-59.
} 
The general principlesof AAOIFI audit are:

a. Auditorsof Islamic financial institutions must comply with the "Code of conduct of accountant profession" issued by AAOIFI and the International Federation of Accountans that does not conflict with the rules and principles of Islam.

b. The auditor should conduct audits according to the standards issued by the Auditing Standards for Islamic Financial Institutions (ASIFIs).

c. The auditors should plan and perform the audits with professional competence, being careful and aware of any circumstances that may exist and cause the financial mistatements.

\section{Ethics Audit Syariah}

As quoted by Sofyan, Sudibyo proposed a social contract theory of ethics, stating that human beings can be said to fulfill the contract with the public if he chooses a moral choice or good, positive, fair, and so forth.

Auditors as professional workers must rely on ethics if the work is considered valuable and much appreciated by the community. The size that the auditor performs with ethical is how far he follows the truth, honesty, behave well, maintain integrity, independence, work carefully and always be aware of the importance of the values of a professional in every process of the implementation of its functions.

\section{Auditing Standards Syariah}

Awareness and economic development of sharia require financial institutions as the standard of shari'ah with the establishment of this institution into directives or guidelines for Shari'ah financial institutions around the world.

The Accounting and Auditing Organizationfor Islamic Financial Institution (AAOIFI), formerly known as the Financial Accounting Organization for Islamic Banks and Financial Institution established on 1 Safar 1410 H or February 26, 1990 in Aljiria.The general principles of the AAOIFI audit include :

a. Auditors of Islamic financial institutions must comply with the "Code of conduct of accountant profession" issued by AAOIFI and the International Federation of Accountants is not against the rules and principles of Islam.

b. The auditors should conduct the audit in accordance with standards issued by the Auditing Standards for Islamic Financial Institutions (ASIFIs).

c. The auditor should plan and perform the audit with professional competence, careful and aware of all the circumstances that may exist and cause mistatements.

The audit found that audit coverage should be made by auditors performing in the audit of Islamic Financial Institutions, called the scope of the audit. The procedures 
required to conduct an audit in accordance with auditing standards for Islamic financial institutions are guided by the the following requirements.

\section{Auditing Standards}

According to Webster's New International Dictionary, a standard is something that is determined by the authorities as a rule to measure the quality, weight, area, value, or quality. Auditing standard is a measure of the implementation of measures which include general guidelines for auditors to perform audits. Auditing standards consist of ten standards and all standard Statement on Auditing (PSA). Auditing standards were established by the Indonesian Institute of Accountants in Statement on Auditing Standards (PSA) No. 01 (SA Section 150) in 2011. PSA is composed of ten standards which are grouped into three major groups ${ }^{15}$.

\section{Research Methods}

\section{Types of Research and Characteristics}

Based on the problems and research objectives, this study used quantitative research that is often called the traditional method. Quantitative research is based on the philosophy of positivism which emphasizes the phenomena studied objectively and quantitatively ${ }^{16}$. Objectivity in quantitative study used figures, statistical processing, structure and controlled trials. This study has associative properties, the research that has the nature of the relationship between two or more variables. The relationship between one variable to another variable, namely symmetric causal and interactive ${ }^{17}$.

Associative referred to in this study is whether there is an influence between education auditor, audit period, and the experience of the auditors on audit quality ${ }^{18}$. This study used purposive sampling where data were taken with the following criteria :

1. The Company listed at the Jakarta Islamic Index (JII) 2008-2014 = 75

2. Companies not delisting at JII 2008-2014 $=68$

3. Companies listing in the JII 2008-2014 with the financial statements which have been audited and expressed as unqualified $=7$

Total companies used as sample $=7$

Total sample $=7$ years $\mathrm{x} 7$ companies $=49$

\footnotetext{
${ }^{15}$ Sukrisno Agoes, Auditing: Petunjuk Praktis Pemeriksaan Akuntan oleh Akuntan Publik, Jakarta, : Salemba Empat, 2012

${ }^{16}$ Nana Syaodih Sukmadinata, Metode Penelitian Pendidikan, (Bandung: PT Remaja Rosdakarya, 2012), Cet. Ke 8, h. 53.

${ }^{17}$ Sugiyono, Op.cit., h. 14

${ }^{18}$ Made Wirartha, Metodologi Penelitian Sosial Ekonomi, (Yogyakarta: Andi Ofsetb, 2006), h.166
} 
Table 1. Population and Sample of Companies listed in Jakarta Islamic Index (JII)

\section{8 - 2014}

$\begin{array}{ccc}\text { Year } & \text { Population } & \text { Sample } \\ 2008 & 21 & 7 \\ 2009 & 20 & 7 \\ 2010 & 9 & 7 \\ 2011 & 4 & 7 \\ 2012 & 8 & 7 \\ 2013 & 6 & 7 \\ 2014 & 7 & 7 \\ \text { TOTAL } & \mathbf{7 5} & \mathbf{4 9}\end{array}$

Source: Adapted Secondary Data JII.

\section{Data Source}

Sources of data were taken from the secondary data. Secondary data have typically been arranged in the form of documents and archives, where researchers must receive dataas they are ${ }^{19}$. Data taken in this study were derived from:

1. Database = OSIRIS: Indonesian Capital Market Directory (ICMD) in 2008-2014.

2. The financial statements of Capital Market Research Center (PRPM) the Stock Exchange in 2008-2014.

3 . The data taken in IDX in 2008-2014.

4. Data from the website of each company in 2008 -2014.

5. Data Public Accountant (AP) and the Public Accounting Firm (KAP) is taken from the database PPAJP - Ministry of Finance and Independent Auditor's Report on the Company's Capital Market Research Center (PRPM).

\section{Data Analysis}

Data Companies In Jakarta Islamic Index (JII)

Based on Jakarta Islamic Index (JII) from 2008 to 2014, there were seven (7) companies. The details of the companies can be seen in the following table :

Table 2. Calculation of Shares Included in the list of Jakarta Islamic Index (JII) 2008 to 2014

\begin{tabular}{|c|l|l|}
\hline NO. & CODE OF FIRMS & \multicolumn{1}{c|}{ FIRMS } \\
\hline 1 & AALI & Astra Agro Lestari Tbk \\
\hline 2 & INTP & Indocemen Tunggal Prakarsa Tbk \\
\hline 3 & KLBF & Kalbe Farma Tbk \\
\hline 4 & PTBA & Tambang Batubara Bukit Asam (Persero) Tbk \\
\hline 5 & SMGR & Semen Indonesia (Persero) Tbk \\
\hline
\end{tabular}

\footnotetext{
${ }^{19}$ Made Wirartha, Metodologi Penelitian Sosial Ekonomi, (Yogyakarta: Andi Offset, 2006), $h$. 245.
} 


\begin{tabular}{|l|l|l|}
6 & TLKM & Telekomunikasi Indonesia Persero Tbk \\
\hline 7 & UNVR & Unilever Tbk \\
\hline
\end{tabular}

\section{Analysis Hypothesis and Discussion}

\section{Classical Assumption Test Results}

Respondents trials in this study were as many as seven companies in Jakarta Islamic Index (JII) going for 7 consecutive years, as many as 49 samples were taken. So, the price is known $\mathrm{df}$ at $5 \%$ level, that is $\mathrm{df}=\mathrm{N}-2=49-2=47$, ie 1,667. Following test results influence research instrument validity period of the audit assignment (X1), education auditor (X2) and the auditor's experience (X3) on audit quality (Y) through the application of SPSS. Data analysis started with the classical assumption. Classic assumption test consisted of five (5) testing: normality, homogeneity, multicollinearity, heteroscedasticity, and autocorrelation.

\section{Normality Test Data}

Testing normality of the data in the study used the Kolmogorov - Smirnov. In the following table, Normality test results are presented using the Kolmogorov Smirnov.The formulation of hypotheses :

HO: Data derived from normally distributed population.

H1: Data come from populations not normally distributed.

Testing criteria:

a) If the value Asymp. Sig. (2-tailed) $<0.05$ then $\mathrm{H} 0$ is rejected.

b) If the value Asymp. Sig. (2-tailed) $<0.05$ then $\mathrm{H} 0$ is accepted.

Table 3. Result Normality Test

\section{One-Sample Kolmogorov-Smirnov Test}

\begin{tabular}{|ll|r|}
\hline & & \multicolumn{2}{|c|}{$\begin{array}{c}\text { Unstandardized } \\
\text { Residual }\end{array}$} \\
\hline $\mathrm{N}$ & Mean & 49 \\
Normal Parameters $^{\mathrm{a}, \mathrm{b}}$ & Std. Deviation & .0000000 \\
& Absolute & .21236018 \\
Most Extreme Differences & Positive & .175 \\
& Negative & .175 \\
& & -.121 \\
Kolmogorov-Smirnov Z & & 1.222 \\
Asymp. Sig. (2-tailed) & & .101 \\
\hline
\end{tabular}

a. Test distribution is Normal.

b. Calculated from data.

Source: Secundary data processed, 2016 
Based on the results of the test output, Kolmogorov- Smirnov presented in Table 3, it can be seen that the significance unstandardized Residual value education, future assignments, and experience on the Quality Audit of 0.101 is more than the value of alpha $(\alpha=0.05)$. Thus, it can be concluded that the data were normally distributed and feasible or qualify the multiple linear regression test.

\section{Homogeneity Test}

The next is testing the homogeneity of variances at least two or more distributions, comparing F countwith $\mathrm{F}$ table inthe table distribution F, with:

a) For the variance of the group with the largest variance, which is dk numerator n-1

b) For the variance of the group with the smallest variance, which is dk denominator n-1

c) If $\mathrm{F}$ arithmetic $<\mathrm{F}$ table, which means homogeneous

d) If $\mathrm{F}$ count $>\mathrm{F}$ table, which means not homogeneous

Table 4. Homogeneity Test Results

Model Summary ${ }^{\text {b }}$

\begin{tabular}{|c|c|c|c|c|c|c|c|c|c|}
\hline \multirow[b]{2}{*}{$\begin{array}{l}\text { Mod } \\
\text { el }\end{array}$} & \multirow[b]{2}{*}{$\mathrm{R}$} & \multirow[b]{2}{*}{$\begin{array}{c}\mathrm{R} \\
\text { Square }\end{array}$} & \multirow[b]{2}{*}{$\begin{array}{l}\text { Adjusted } \\
\text { R Square }\end{array}$} & \multirow[b]{2}{*}{$\begin{array}{l}\text { Std. Error } \\
\text { of the } \\
\text { Estimate }\end{array}$} & \multicolumn{5}{|c|}{ Change Statistics } \\
\hline & & & & & $\begin{array}{c}\text { R } \\
\text { Square } \\
\text { Change }\end{array}$ & $\begin{array}{c}\mathrm{F} \\
\text { Change }\end{array}$ & df1 & df2 & $\begin{array}{c}\text { Sig. F } \\
\text { Change }\end{array}$ \\
\hline 1 & $.999^{\mathrm{a}}$ & .997 & .997 & .219 & .997 & $\begin{array}{r}5048.93 \\
2\end{array}$ & 3 & 45 & .000 \\
\hline
\end{tabular}

a. Predictors: (Constant), X3, X2, X1

b. Dependent Variable: kualitas_audit

Source: Scondary data processed, 2016

Based on testing with SPSS, output of Anova table Anova test is obtained, presented in Table 4 based on the results of ANOVA test or F test between educational variables auditor, future audits, and the auditor's experience on the Quality Audit calculated $F$ value of 5048.932 to the level of significance probability of 0.000 . The study concluded that the model is not homogeneous. F test is used to determine the effect of independent variables (simultaneously) on the dependent variable.

The test results can be seen in the table above. If $\mathrm{F}$ arithmetic $>\mathrm{F}$ table with $\mathrm{dk} \mathrm{dk}$ numerator and denominator $\mathrm{k} \mathrm{n-k-1}$ as well as the use of certain $\alpha$, then $\mathrm{H} 0$ is rejected or if otherwise F count $>\mathrm{F}$ table then $\mathrm{H} 0$ is accepted. From the analysis of the data with SPSS, F count $=5048.932$ significance (sig.) was obtainedof 0.000 while the $\mathrm{f}$ table with degrees of freedom ( df / df) for the numerator and denominator $=3=45$ and $\alpha=0.05$ from the list of tables obtained $=1,667$. Therefore $F$ count $>F$ table or 5048.932> 1,667.Then, there is no homogeneity. 


\section{Test Multicolinearity}

Multicolinearity test aims to test whether the regression equation found a correlation between independent variables. Multicolinierity test was conducted with a view tolerance value or by using the Variance Inflation Factors (VIF) of the results of analysis using SPSS.

Multicolinearity test was done by looking at the tolerance value and variance inflation factor (VIF). Multicollinearity occurs when VIF above a value of 10 or below the tolerance value of 0.10 . Multicollinearity does not occur when the VIF values are below 10. Multicollinearitytest calculation results can be seen in Table 5 .

Table 5. Multicollinearity Test Results

\section{Coefficients $^{\mathbf{a}}$}

\begin{tabular}{|l|c|c|c|c|c|c|c|}
\hline \multirow{2}{*}{ Model } & \multicolumn{2}{|c|}{$\begin{array}{c}\text { Unstandardized } \\
\text { Coefficients }\end{array}$} & $\begin{array}{c}\text { Standardized } \\
\text { Coefficients }\end{array}$ & \multirow{2}{*}{$\mathrm{t}$} & \multirow{2}{*}{ Sig. } & \multicolumn{2}{c|}{$\begin{array}{c}\text { Collinearity } \\
\text { Statistics }\end{array}$} \\
\cline { 2 - 5 } \cline { 6 - 9 } & $\mathrm{B}$ & Std. Error & Beta & & & $\begin{array}{c}\text { Toleranc } \\
\mathrm{e}\end{array}$ & $\mathrm{VIF}$ \\
\hline 1 (Constant) & -.791 & .202 & & -3.906 & .000 & & \\
$\mathrm{X} 1$ & 1.242 & .012 & 1.070 & 104.045 & .000 & .623 & 1.606 \\
$\mathrm{X} 2$ & -.085 & .017 & -.043 & -5.120 & .000 & .917 & 1.091 \\
$\mathrm{X} 3$ & -.082 & .007 & -.118 & -11.747 & .000 & .647 & 1.545 \\
\hline
\end{tabular}

a. Dependent Variable: audit Quality

According to Table 5, Variance Inflation Factor (VIF) showsthat all independent variables have VIF <10. It can be concluded that there is no multicollinearity between independent variables in the model or no correlation between independent variables.

\section{Heteroscedasticity Test}

Heteroscedasticity is inequality variants of residuals for all observations in the regression model. This test was done in order to determine any deviation from the terms of the classical assumptions on the regression model. To determine the existence of heteroscedasticity in this study scatterplot graph was used. In the attached picture, dependent variable is the quality of the audit shown by dots spreading below and above zero and does not form a specific pattern.

Thus, it can be said that it does not happen that heteroscedasticity the regression model. So, it is worth used to predict the quality of education audits by independent variables auditor, audit period, and the auditor's experience. 
Graph 1. Scatter plot Graph

\section{Scatterplot}

Dependent Variable: kualitas_audit

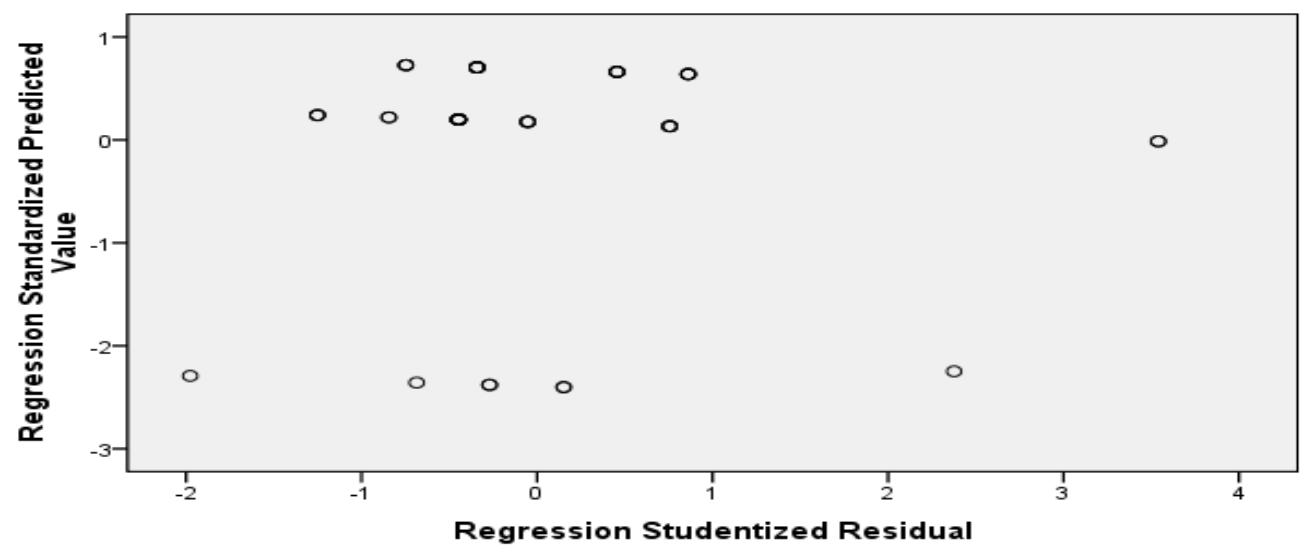

\section{Autocorrelation Test}

Autocorrelation test is used to see if there is a linear relationship between the error range of observation sorted by time (time series data). Autocorrelation test needs to be done if the analyzed data are the data time series. Autocorrelation test is done by using the Durbin-Watson test formula.The formulation of hypotheses:

HO: No autocorrelation between observational data.

H1: There was a presence of autocorrelation between the observational data.

Testing criteria:

a) If the Durbin-Watson statistic values approaching 2, it has no autocorrelation.

b) If the Durbin-Watson statistic value away from number 2, it has no autocorrelation.

Table 6. Autocorrelation Test

Model Summary ${ }^{b}$

\begin{tabular}{|c|c|c|c|c|c|c|c|c|c|c|}
\hline \multirow[b]{2}{*}{ Model } & \multirow[b]{2}{*}{$\mathrm{R}$} & \multirow{2}{*}{$\begin{array}{c}\mathrm{R} \\
\text { Square }\end{array}$} & \multirow{2}{*}{$\begin{array}{l}\text { Adjusted } \\
\text { R Square }\end{array}$} & \multirow{2}{*}{$\begin{array}{l}\text { Std. Error } \\
\text { of the } \\
\text { Estimate }\end{array}$} & \multicolumn{5}{|c|}{ Change Statistics } & \multirow{2}{*}{$\begin{array}{l}\text { Durbin- } \\
\text { Watson }\end{array}$} \\
\hline & & & & & $\begin{array}{l}\text { R Square } \\
\text { Change }\end{array}$ & F Change & df1 & df2 & $\begin{array}{c}\text { Sig. F } \\
\text { Change }\end{array}$ & \\
\hline 1 & $.999^{\mathrm{a}}$ & .997 & .997 & .219 & .997 & 5048.932 & 3 & 45 & .000 & 1.734 \\
\hline
\end{tabular}

a. Predictors: (Constant), X3, X2, X1

b. Dependent Variable: Audit Quality

Source: Scondary data processed, 2016 
The autocorrelation test was done by comparing the value DW, DW statistic table 6 with the formula DW. The results obtained by the analysis of DW count of 1.734 is then compared with DW tables. As for looking DW table is to find the value of d1 and du to the following criteria:

a) The number of independent variables $=3$

b) The number of samples $=49$

c) The confidence level of $95 \%$ and $\alpha=5 \%$

$\mathrm{d} 1=1.42$

$\mathrm{du}=1.67$

The result of these tests DW test value of 1.734 is greater than du (1.67) and smaller than 4 - du $(2.33)$ or $(1.67<1.734<2.33)$. Thus, it can be concluded that there is no autocorrelation in this study.

\section{Analysis Hypothesis Testing}

\section{Multiple Linear Regression Test}

The statistical tool used to test hypothesis is linear regression. Multiple linear regression analysis is used to describe the value of the dependent variable that can increase or decrease and to determine the direction of the relationship between independent and dependent variables. To see the effect, the period of the audit assignment (X1), education auditor (X2), and the auditor's experience (X3) on audit quality (Y) is done by looking at the table of coefficients and comparing the magnitude of the p-value in the column sig <level of significant $(\alpha) 0.05$.

Seen from the table on the testing of hypothesis, multiple linear line equation is obtained:

$$
\mathrm{Y}=-0.791+1.242 \boldsymbol{X}_{1-0,085} \boldsymbol{X}_{2-} 0.082 \boldsymbol{X}_{3+\mathrm{e}}
$$

Table7. The Results of Multiple Linear Regression Test

\section{Coefficients $^{\text {a }}$}

\begin{tabular}{|c|c|c|c|c|c|c|}
\hline & \multirow[t]{2}{*}{ Model } & \multicolumn{2}{|c|}{$\begin{array}{l}\text { Unstandardized } \\
\text { Coefficients }\end{array}$} & \multirow{2}{*}{$\begin{array}{c}\begin{array}{c}\text { Standardized } \\
\text { Coefficients }\end{array} \\
\text { Beta }\end{array}$} & \multirow[b]{2}{*}{$\mathrm{T}$} & \multirow[b]{2}{*}{ Sig. } \\
\hline & & B & Std. Error & & & \\
\hline \multirow[t]{4}{*}{1} & (Constant) & -.791 & .202 & & -3.906 & \multirow{4}{*}{$\begin{array}{l}.000 \\
.000 \\
.000 \\
.000\end{array}$} \\
\hline & $\mathrm{X} 1$ & -.085 & .017 & -.043 & -5.120 & \\
\hline & $\mathrm{X} 2$ & 1.242 & .012 & 1.070 & 104.045 & \\
\hline & $\mathrm{X} 3$ & -.082 & .007 & -.118 & -11.747 & \\
\hline
\end{tabular}

a. Dependent Variable: Quality_audit

Source: Scondary data processed, 2016 
According to table 7 there is a relationship between the variables, the period of the audit assignment (X1), education auditor (X2) and the auditor's experience (X3) on audit quality (Y), namely:

a) The constant $\mathrm{a}=-0.791$ and the coefficient $\mathrm{b} 1=-0.85$, coefficient $\mathrm{b} 2=1.241$, and the coefficient $b 3=-0.082$. The constant $a$ by -0.791 states that if there is no value, the period of the audit assignment (X1), education auditor (X2) and the auditor's experience $(\mathrm{X} 3), \mathrm{X}=0$, then the value of audit quality of -0.791 .

b) b1 coefficient -0.085 worth stating that each additional unit of $X$ variable future audits will increase audit quality by -0.085 if other variables are constant. The coefficient is negative means there is a negative relationship between past audits by audit quality. The longer the period of the audit assignment it will lower the quality of the audit.

c) The coefficient b2 worth 1.241 states that each additional unit of $\mathrm{X}$ variable auditor education will improve the quality of audits of 1,241 if other variables are constant. The coefficient is positive means that there is a positive relationship between education auditor to audit quality. The higher the education, the auditor would improve audit quality.

d) The coefficient b3 worth -0.082 states that each additional unit of $\mathrm{X}$ variable auditor's experience will improve the quality of audits by -0.082 if other variables are constant. The coefficient is negative means there is a negative relationship between the auditor's experience with audit quality. The longer the auditor's experience will degrade the quality of the audit.

\section{The Coefficient Of Determination (R2)}

Determination test is used to determine the effect of variable percentage of the contribution, the period of the audit assignment (X1), education auditor (X2) and the auditor's experience (X3) together on the variable quality of the audit (Y). R2 test performed with SPSS 17 that the results in Table 8 as follows:

Table 8. Coefficient Determination Adjusted R Square

Model Summary ${ }^{b}$

\begin{tabular}{|c|c|c|c|c|}
\hline Model & $\mathrm{R}$ & $\mathrm{R}$ Square & Adjusted R Square & Std. Error of the Estimate \\
\hline 1 & $.999^{\mathrm{a}}$ & .997 & .997 & .219 \\
\hline
\end{tabular}

a. Predictors: (Constant), X3, X2, X1

b. Dependent Variable: Audit Quality

Source: Secundary data processed, 2016

Based on the results of the model calculation summary in table 8 Coefficient of Determination that the quantity adjusted R2 is 0.997 this means that $99.7 \%$ of the variation can be dijelas the audit quality by a third variation of the independent variable is time audit, auditor training and experience of the auditor. This indicates that the level of past relationships audit, the auditor's education and 
experience of auditors with audit quality, including the strong category amounted to $99.7 \% .99 .7 \%$ of audit quality is affected period audit, the auditor's education and experience of auditors, while the remaining $0.3 \%$ is explained by other causes outside the model.

\section{Analysis Hypothesis Testing (Test F)}

Table 9. Simultaneous Test Results (F)

ANOVA $^{b}$

\begin{tabular}{|ll|r|r|r|c|c|}
\hline Model & & Sum of Squares & Df & Mean Square & F & Sig. \\
\hline 1 & Regression & 728.611 & 3 & 242.870 & 5048.932 & $.000^{\mathrm{a}}$ \\
& Residual & 2.165 & 45 & .048 & & \\
& Total & 730.776 & 48 & & & \\
\hline
\end{tabular}

a. Predictors: (Constant), X3, X2, X1

b. Dependent Variable: Quality_audit

Based on testing with Anova SPSS output obtained at Anova Test table in table 9. Based on the results of ANOVA test or F test between educational variables auditor, audit period, and the auditor's experience on the Quality Audit calculated F value of 5048,938 to the level of significance probability of 0.000 so it can be concluded that the research model worthy or fit.

$F$ test is used to determine the effect of independent variables jointly (simultaneously) on the dependent variable. The test results can be seen in the output $\mathrm{F}$ ANOVA table above. If $\mathrm{F}$ arithmetic $>\mathrm{F}$ table with $\mathrm{dk} \mathrm{dk}$ numerator and denominator $\mathrm{k} \mathrm{n}-\mathrm{k}-1$ as well as the use of certain $\alpha$ then $\mathrm{H} 0$ is rejected or if otherwise F count $>\mathrm{F}$ table then H0 is accepted. From the analysis of the data with SPSS obtained $\mathrm{F}$ count $=5048.932$ significance (sig.) Of 0.000 while the $\mathrm{f}$ table with degrees of freedom (df / df) for the numerator and denominator $=3=45$ and $\alpha=$ 0.05 from the list of tables obtained $=1,667$ therefore $F$ count $>F$ table or 5048.932> 1667 then $\mathrm{H} 0$ and accept $\mathrm{H} 1$ stating that there is the influence of education auditor, audit period, and the experience of the auditor to audit quality.

Effect of education variable auditors, past audits, and experience of the auditor to audit quality simultaneously can be seen from the $\mathrm{F}$ test that returns a value of FF arithmetic> F table or 5048.932> 1667 then $\mathrm{H} 0$ and accept $\mathrm{H} 1$ stating that there is the influence of education auditor, future assignments audit, and the auditor's experience on the Quality audit. The closeness of education influence auditor, audit period, and the experience of the auditors on audit quality is indicated by the coefficient of determination on the Adjusted R-Square is 0.997 or $99.7 \%$.

This suggests that the education level of closeness of auditors, audit period, and the experience of the auditors on audit quality, including the strong category that is 
equal to $99.7 \%$. So that $99.7 \%$ of audit quality education influenced auditor, audit period, and the experience of the auditor and the remaining $3 \%$ is influenced by other variables that are not included in this study.

This is in accordance with the opinion of Kasim \& Sanusi; Kasim Nawal, Shahul Hameed Sulaiman Mohamad Ibrahim \& Maliah stating that audit quality is affected competency that consists of education (knowledge) and the experience and competence of audit quality is also affected, one of which is the period of the audit assignment.

Component quality audit consists of a way to measure the quality of the auditor's work is through independence and competence. Independent means that the auditor is impartial and not biased toward audited financial information as well as the preparers and users of financial statements. One component satau independence is the ideal time to do the assignment. In the early days of the assignment, the auditor will be biased towards the information from the client company for the first time examined the financial statements, have not understood the client company.

However indepensi also could erode if the auditor has long been auditing a company then created a bond relationship that is too close to the client ${ }^{20}$. Competence is the auditor's ability to implement and complete the task. Auditor competence can be measured from the education and experience of Certified Public Accountants. Education of accounting proves that the auditor has good credibility. Public Accounting Firm has a lot of work accounting education standards compliant audit so experienced and good audit quality. In this hypothesis test to answer the problem formulation.

Thus the results of this study support previous research Kasim \& Sanusi; Kasim Nawal, Shahul Hameed Sulaiman Mohamad Ibrahim \& Maliah stating that audit quality is affected auditor competence such as education and experience as well as the independence of the auditor in the form of future audits. Auditor shariah at JII must be trained in accountancy with special certification in the Shariah as auditor. This is to increase the competence of the auditors. Audit Shariah should also be carried out in accordance with auditing standards AAOFI. While corporate governance in JII let maximized in order to fulfill its corporate social responsibility. The period of audit, education audit and audit experience is important in auditing.

Auditors working with the longer period of the assignment, the higher education and the longer the experience will affect audit quality, the better. With good quality audit the auditor apply fairly and without bias. The financial statements have good audit quality would be beneficial for the company and outside the company. Outside parties with an interest in the financial statements will be highly trust financial

\footnotetext{
${ }^{20}$ Abdul Halim, Auditing 1: Dasar-dasar Audit Laporan Keuangan. (Yogyakarta: UPP AMP YKPN, 2004), h. 21.
} 
statements with the auditor's report were reasonable. So that outside parties will suffer if the auditor affect covering fraud companies.

\section{Conclusion}

The conclusion of the presentation of results and data analysis in this study in accordance with the formulation of research problems are as follows:

There is the influence of education auditor, audit period, and the auditor's experience on the Quality Audit. It can be seen from the F test that produces value F F count> F table or 5048.932> 1,667. The higher the education of auditors, auditor assignment period, and the auditor's experience together will further improve the quality of audit the auditor who audited the companies listed in the Jakarta Islamic Index (JII).

Thus the results of this study support previous research Kasim \& Sanusi; Kasim Nawal, Shahul Hameed Sulaiman Mohamad Ibrahim \& Maliah stating that audit quality is affected auditor competence such as education and experience as well as the independence of the auditor in the form of future audits. Auditor shariah at JII must be trained in accountancy with special certification in the Shari'ah as auditor. This is to increase the competence of the auditors. Audit Shariahshould also be carried out in accordance with auditing standards AAOFI. While corporate governance in JII let maximized in order to fulfill its corporate social responsibility.

Audit sharia yet fully implemented in countries which use sharia accounting, such as in Indonesia, Malaysia, Brunei, Iran, and Pakistan. Audit sharia generally still refer to the auditing guidelines applicable national origin is not at odds with the sharia. Audit sharia has obstacles in its development, for example: the lack of auditors qualified understanding of accounting and sharia together, the lack of universities that provide syllabuses audit sharia, yet the implementation of the standard auditor sharia made by the Accounting and Auditing Organization for Islamic Financial intitutions (AAOIFI) and the lack of government regulation of audit liability companies incorporated in the islamic capital market by Sharia auditor.

\section{Recommendations}

Based on these conclusions, the following recommendations are given:

1. Auditors who audited Islamic financial institutions, particularly in the Islamic capital markets should have adequate competence of education and Islamic accounting. Theauditors must continue to improve continuing education and knowledge in order to understand the rules and concepts that they apply. Regarding the lack of human resources who understand the syariah auditor simultaneously accounting knowledge and sharia, the need to improve the competence of shariah audit both formal and informal education. Accounting syllabus introduction of sharia and sharia audits can be done formally since the 
level of Senior High School (SMA), continued at the school level Sharia audit profession, diploma, undergraduate, postgraduate, and three strata. Non-formal education could be done at training and certification levels either for internal audit certificate and sharia public audit certificate. It is the obligation of government that those audits of Islamic financial institutions must have a certificate of shariah audit.

2. The auditor should be able to use his experience well that doing a careful and thorough audit and ethics and avoid using ego. Expected experienced senior auditor can direct and share knowledge to junior auditor.

3. Increased competence of auditors of sharia could be by increased research shariah audit, procurement competitions related to shariah audit, the availability of books and journals are still limited sharia audit.

4. The auditor must be independent so that auditing is not affected by the wishes of the client so that the results can be trusted by the user auditing financial statements. The auditor must follow the rules of Bapepam about the assignment of auditors apply.

5. Bapepam, that the Chairman of Bapepam-LK No. 86/2011, revising the Chairman of Bapepam-LK No. 20/2002 about the prescribed period of Public Accounting Firm. If previously Public Accounting Firm is not allowed to audit the same client before the break of three years, is now commuted to pause one year only. It is as happened in Coal Mine Bukit Asam (Persero) Tbk, where after three years with the same Public Accountant, but after the fourth year to be replaced by a Public Accountant others, in the fifth year changed to the same Public Accountant previously even with Public Accounting Firm names are different. It is seen to lack of auditor independence. The longer the period of the relationship means the closer the relationship between auditor and client. The closeness of this relationship could ultimately lead to a conflict of interest within the auditor. The case of Arthur Andersen in the Enron scandal could be an example.

6. Suggestions for Bapepam, that that the Chairman of Bapepam-LK No. 86/2011 which revised the Chairman of Bapepam-LK No. 20/2002 mentionsPublic Accounting Firm can provide audit services 6 consecutive years. The period of this assignment is longer than the previous regulations which require the maximum limit of five years to five years in Public Accounting Firm is often abused by Public Accounting Firm, where Public Accounting Firm different audit firm, but still Public Accounting Firms audit company Similarly, Public Accounting Firms is still under the same international affiliates. It is seen to lack of auditor independence. For the future need to be put in place that limit the discretion of the firm in a company for five years and Public Accounting Firm successors are not under the same international affiliates.

7. Government Regulation on Public Accountant No. 20. 2015 Article 11, namely on the granting of an entity by a Public Accountant is limited at most 5 consecutive years. Public Accountant audit can give back to the same entity after two consecutive years of not providing the service. 


\section{References}

Abdul Halim, (2004). Auditing 1: Dasar-dasar Audit Laporan Keuangan. Yogyakarta: UPP AMP YKPN.

Suharli, M. (2006). Audit Finansial, Audit Manajemen dan Sistem Pengendalian Intern. Jurnal Bisnis dan Ekonomi,(Online), Volume3, No.1.pp 36-37.

Ibnu Irawan et al, (2014). “Pengaruh Kompetensi, Skeptisme, Hubungan Klien Dengan Auditor, Ukuran KAP Terhadap Kepuasan Klien Dan Kegunaan Untuk Stakeholder Eksternal Dalam Prespektif Klien. "Jurnal \& Prosiding SNA-Simposium Nasional Akuntansi, Vol. 17, NTB.

I Made Wirartha (2006), Metodologi Penelitian Sosial Ekonomi, Yogyakarta: Andi Ofsetb,pp. 166-167.

Januarti, Indira. “Analisis Pengaruh Faktor Perusahaan, Kualitas Auditor, Kepemilikan Perusahaan Terhadap Penerimaan Opini Audit Going Concern (Perusahaan Manufaktur yang Terdaftar di Bursa Efek Indonesia).", Universitas Diponegoro.

Kasim \& Sanusi (2013), "Emergingissues for auditing in Islamic Financial Institutions: Empiri calevidence from Malaysia. "IOSR Journal of Business and Management. Universiti Teknologi MARA, Malaysia, Volume 8, Issue 5, Mar-Apr.

Kasim Nawal, Zuraidah Mohd Sanusi, Tatik Mutamimah, dan Sigit Handoyo, (2013), "Assessing the current practice of Auditingin Islamic Financial Institutions in Malaysia and Indonesia", International Journal of Trade, Economics and Finance, Vol. 4, No. 6.

Made Wirartha, (2006), Metodologi Penelitian Sosial Ekonomi, Yogyakarta,Andi Offset. Mulyadi, (2011), Auditing, Edisi 6. Buku 1 dan 2, Jakarta, Salemba Empat.

Nana Syaodih Sukmadinata (2012), Metode Penelitian Pendidikan, Bandung, PT Remaja Rosdakarya, Cet. Ke. 8.

Nawal Kasim, Zuraidah Mohd Sanusi, Tatik Mutamimah, \& Sigit Handoyo, (2013), "Assessing the current practice of Auditingin Islamic Financial In stitutionsin Malaysia and Indonesia", International Journal of Trade, Economics and Finance, Vol. 4, No. 6. pp. 2.

Sugiyono, (2013), “Metode Penelitian Kuantitatif Kualitatif Dan $R \&$ D”. Bandung, Alfabeta.

Sukrisno Agoes, (2012), “Auditing: Petunjuk Praktis Pemeriksaan Akuntan oleh Akuntan Publik", Jakarta, Salemba Empat.

Suryanto, T. (2014). Determinants of Audit Fee Based on Client Attribute, Auditor Attribute, and Engagement Attribute to Control Risks and Prevent Fraud: A Study on Public Accounting Firms in Sumatra-Indonesia. International Journal in Economics and Business Administration, 2(3), 27-39.

Wirartha, Made, (2006), “Metodologi Penelitian Sosial Ekonomi”, Yogyakarta: Andi.www.iapi.or.id

Yacoob \& Donglah, (2012), "Shari'ah Audit in Islamic Financial Institutions: The Postgraduates' Perspective Audit Syariah di Lembaga Keuangan Islam: The pasca sarjana 'Perspektif. "International Journal of Economics and Finance. University of Brunei Darussalam,Brunei .Vol.4,No.12. pp. 3.

Zurina Shafii, Nor Aishah Mohd Aliand Nawal Kasim, (2014), "Shariah auditin Islamic banks: aninsight to the future shariah auditor labourmarketin Malaysia Audit Syariah di bank syariah", Procedia Social and behavioral science, www.sciencedirect.com. pp. 2. 